\title{
Physical and Mechanical Properties of Black Wood (Ebony) as a Construction Material
}

\author{
Fengky Satria Yoresta \\ Department of Forest Product, Faculty of Forestry \\ Bogor Agricultural University, Bogor \\ syfengky@gmail.com
}

\begin{abstract}
This research is aimed to determine physical and mechanical properties of Ebony wood as a construction material. The physical and mechanical properties test is conducted based on ASTM D 143-94 code. The mean value of moisture content and specific gravity of Ebony wood is obtained $12,90 \%$ and $0,92{\mathrm{gr} . \mathrm{cm}^{-3}}^{-3}$ respectively. Meanwhile MOE, bending strength, compressive strength parallel to grain, shear strength, and tensile strength parallel to grain are $180.425,87 \mathrm{~kg} \cdot \mathrm{cm}^{-2} ; 1656,22 \mathrm{~kg} \cdot \mathrm{cm}^{-2} ; 861,55 \mathrm{~kg} \cdot \mathrm{cm}^{-2} ; 119,61 \mathrm{~kg} \cdot \mathrm{cm}^{-2}$; dan $2.319,03 \mathrm{~kg} \cdot \mathrm{cm}^{-2}$ respectively. Based on the test results, it can be concluded that Ebony wood is classified to Strength Class I due to PKKI 1961, so it can be recommended for use in heavy construction such as bridge and building structures.
\end{abstract}

Keywords: physical properties, mechanical properties, Ebony wood

\begin{abstract}
ABSTRAK
Penelitian ini bertujuan menentukan sifat fisis dan mekanis kayu Ebony sebagai material konstruksi. Pengujian sifat fisis dan mekanis dilakukan berdasarkan standar ASTM D 143-94. Nilai kadar air rata-rata kayu Ebony diperoleh sebesar $12,90 \%$ dan berat jenis $0,92 \mathrm{gr}_{\mathrm{cm}} \mathrm{cm}^{-3}$. Sementara nilai rata-rata MOE, kuat lentur, kuat tekan sejajar serat, kuat geser, dan kuat tarik sejajar serat berturut-turut adalah $180.425,87 \mathrm{~kg} . \mathrm{cm}^{-2} ; 1656,22 \mathrm{~kg} . \mathrm{cm}^{-2} ; 861,55 \mathrm{~kg} . \mathrm{cm}^{-2}$; $119,61 \mathrm{~kg} \cdot \mathrm{cm}^{-2}$; dan $2.319,03 \mathrm{~kg} \cdot \mathrm{cm}^{-2}$. Berdasarkan hasil penelitian dapat disimpulkan bahwa kayu Ebony tergolong kelas kuat I menurut PKKI 1961, sehingga dapat direkomendasikan untuk digunakan pada konstruksi-konstruksi berat seperti jembatan dan struktur bangunan.
\end{abstract}

Kata Kunci: sifat fisis, sifat mekanis, kayu Ebony

\section{Introduction}

Good quality material is one of the main requirements to be able to create a strong building (Boen 2009). Wood is a material that has a good properties in ductile compared to other construction materials such as concrete. Therefore, the use of wood is in great demand, especially for residential construction. In United Sates, more than $80 \%$ of all buildings are wood construction (Aghayere et al. 2007).

Wood is widely used for dwelling houses, especially in rural areas either as a building frame (columns and beams) or as a roof truss (Figure 1). Such function requires that the timber used carry a heavy load, including the weight of non-structural building components.

Ebony wood which is also known as black wood was used by Indonesian traditional society in ancient times because of hard and strong. However, its use as a construction material even until now is not based on scientific knowledge to the mechanical properties of it which is the core of understanding, but through the experience gained by generations from their ancestors. It would be fatal if there is external load exceeds the wood strength capacity.

For example is when houses are shaked by an earthquake. The survey showed that $25 \%$ of wood-frame dwelling houses 
sustained losses more than $5 \%$ of the dwelling's value on San Fernando earthquake California 1971 (Yancey et al.1998). The damage could starts from destruction of wood component on the houses. That is why the basic properties of wood (mechanical and physical) should be known well to be taken into account in structural design.

The mechanical properties of wood that most commonly measured and represents the "strength properties" consists of tensile strength parallel to grain, compressive strength perpendicular to grain, tensile strength perpendicular to grain, flexural strength, compressive strength parallel to grain, as well as shear strength and hardness. Construction experts will consider that values of mechanical properties in buildings structural design, especially for large scale of wood frame constructions.

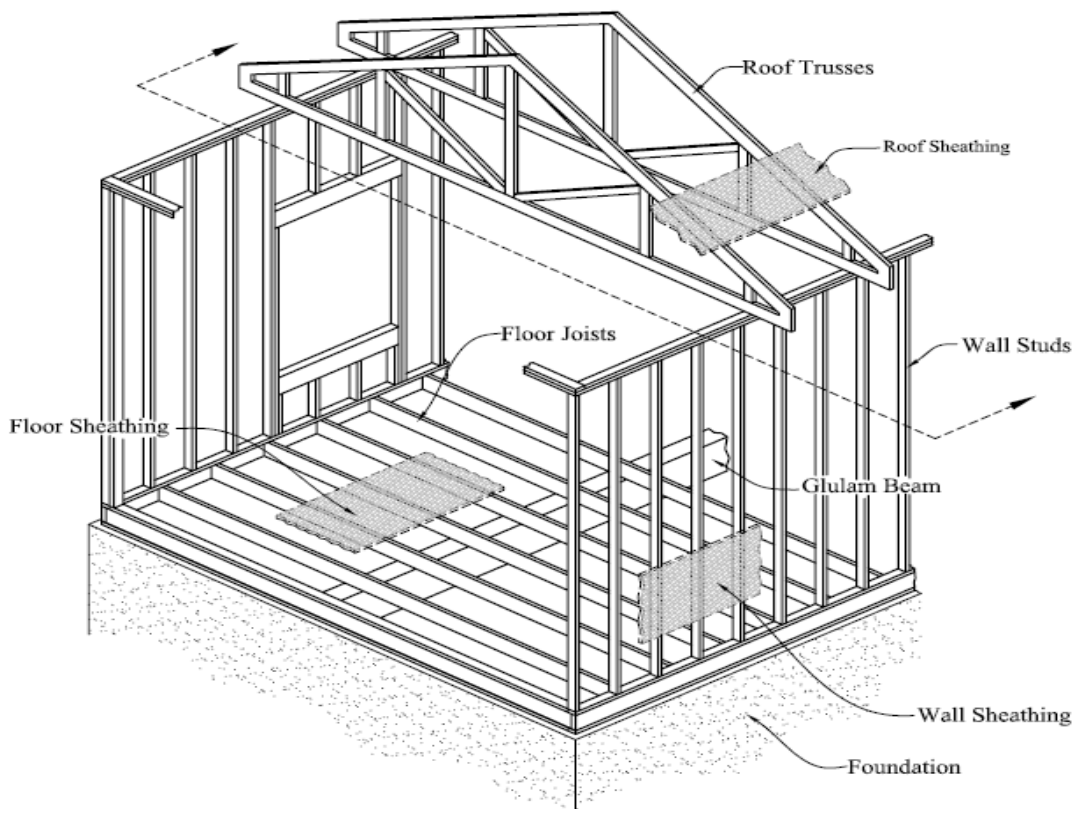

Figure 1: Typical structural components of wood buildings. Source: Aghayere et al., 2007

\section{Materials and Methods}

Ebony wood in this study was obtained from Sulawesi island, Indonesia. Testing of physical and mechanical properties of Ebony is conducted using 5 tons capacity of Instron machine and based on code ASTM D 143-94 (Figure 2). A total of 20 test samples was prepared for each test. Physical properties tested consist of moisture content and specific gravity. While the mechanical properties tested consist of Modulus of Elasticity (MOE), bending strength, compressive strength parallel to grain, shear strength and tensile strength parallel to grain. The test results are then analyzed and classified based on the Indonesian Timber Construction Code (PKKI) 1961.
Specific gravity $\mathrm{G}$ is calculated by ratio of the density of the wood to the density of water $\rho_{w}$ at a specified reference temperature, typically $4^{\circ} \mathrm{C}\left(39^{\circ} \mathrm{F}\right)$, where $\rho_{w}$


expressed as a percentage and calculated by

$$
\mathrm{MC}=\frac{m_{\text {wet }}-m_{\mathrm{dry}}}{m_{\mathrm{dry}}}(100 \%)
$$

where $m_{\text {wet }}$ is the mass of the specimen at a given moisture content and $m_{d r y}$ is the mass of the ovendry specimen.

Modulus of Elasticity (MOE) and bending strength $\left(\sigma_{\mathrm{lt}}\right.$ or MOR) are calculated by 
equation (2) and (3) respectively. Meanwhile, compressive strength parallel to grain $\left(\sigma_{\mathrm{tk}} / /\right)$, shear strength ( $\mathrm{T})$ and tensile strength parallel to grain $\left(\sigma_{\mathrm{tr}} / /\right)$ are calculated by equation (4).

$$
\begin{gathered}
M O E=\frac{P L^{3}}{4 \Delta b h^{3}} \\
M O R=\frac{3}{2} \frac{P L}{b h^{2}} \\
\sigma_{\mathrm{tk}} / /, \tau, \text { or } \sigma_{\mathrm{tr}}=P / A
\end{gathered}
$$

where $P$ is maximum load, $L$ is bending span, $\Delta$ is deflection, $b$ is section width, $h$ is section thickness, and $A$ is area (compressive, shear, or tensile). Especially for equation (2), $P$ is load is elastic area of bending curve.

\section{Result and Discussion}

Indonesian Timber Construction Code (PKKI) 1961 divide wood into five classes strength level plus teak wood namely class I, II, III, IV, and V (Table 1). These classes are distinguished based on the strength of wood. Wood in class I and II is also known as structural timber because it is used for manufacture of heavy constructions such as bridges (girder and floor) and bulding structure (column, beam and floor). Wood in class I has a specific gravity greater than 0.90 , while in class II has a specific gravity between 0.60 to 0.90 . Table 3 shows a comparison of physical and mechanical properties of Ebony and some wood in class I and II.

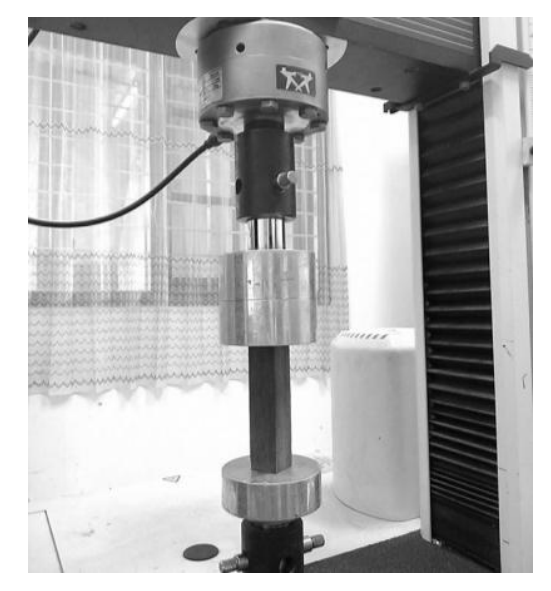

(a)

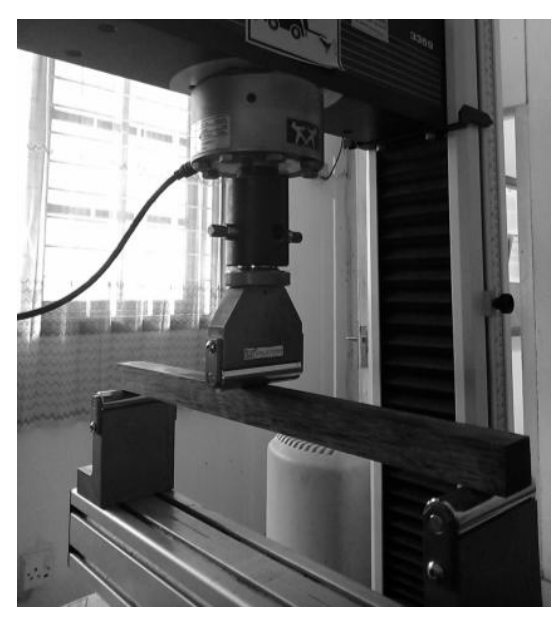

(b)

Figure 2 : Typical test setup: (a) compression parallel to grain, (b) bending test 
Table 1: Wood classification based on strength (PKKI 1961)

\begin{tabular}{|c|c|c|c|c|c|c|}
\hline \multirow{2}{*}{ Strength level } & \multirow{2}{*}{$\begin{array}{l}\text { Specific gravity, } \\
\text { air dry condition } \\
\qquad\left(\mathrm{gr}^{\left.-\mathrm{cm}^{-3}\right)}\right.\end{array}$} & \multirow{2}{*}{$\begin{array}{c}\text { MOE } \\
\left(\mathrm{kg} \cdot \mathrm{cm}^{-2}\right)\end{array}$} & \multicolumn{4}{|c|}{ Allowable stress $\left(\mathrm{kg} \cdot \mathrm{cm}^{-2}\right)$} \\
\hline & & & $\sigma_{\mid t} / /$ & $\sigma_{\mathrm{tr}} / l=\sigma_{\mathrm{tk}} / /$ & $\sigma_{\mathrm{tk}}^{\perp}$ & $\mathrm{T} / /$ \\
\hline teak wood & 0,70 & - & 130 & 110 & 30 & 15 \\
\hline I & $>0,90$ & 125.000 & 150 & 130 & 40 & 20 \\
\hline II & $0,90-0,60$ & 100.000 & 100 & 85 & 25 & 12 \\
\hline III & $0,60-0,40$ & 80.000 & 75 & 60 & 15 & 8 \\
\hline IV & $0,40-0,30$ & 60.000 & 50 & 45 & 10 & 5 \\
\hline V & $<0,30$ & - & - & - & - & - \\
\hline $\begin{array}{ll}\text { Note, } & \sigma_{\mathrm{t} t} / / \\
& \sigma_{\mathrm{t}_{\mathrm{r}} / /} \\
& \sigma_{\mathrm{t} \mathrm{k}} / /\end{array}$ & $\begin{array}{l}\text { flexural strength parallel } \\
\text { tensile strength parallel } \\
\text { compressive strength pe }\end{array}$ & $\begin{array}{l}\text { grain } \\
\text { grain } \\
\text { llel to grain }\end{array}$ & $\begin{array}{l}\sigma_{\mathrm{tk} \perp} \\
\mathrm{T} / /\end{array}$ & $\begin{array}{l}\text { compressive str } \\
\text { : shear strength } p\end{array}$ & $\begin{array}{l}\text { perper } \\
\text { I to gra }\end{array}$ & o grain \\
\hline
\end{tabular}

Table 2: The average value of physical and mechanical properties of Ebony

\begin{tabular}{lcr}
\hline \multicolumn{1}{c}{ Physical and mechanical properties } & Range & \multicolumn{1}{c}{ Mean* } \\
\hline Moisture content, $\mathrm{MC}(\%)$ & $9,18-16,82$ & 12,90 \\
Specific gravity, $\mathrm{G}\left(\mathrm{gr} \cdot \mathrm{cm}^{-3}\right)$ & $0,86-1,21$ & 0,92 \\
Modulus of Elasticity, $\mathrm{MOE}\left(\mathrm{kg} \cdot \mathrm{cm}^{-2}\right)$ & $111.411,23-215.771,95$ & $180.425,87$ \\
Bending strength, $\sigma_{\mathrm{tt}}\left(\mathrm{kg} \cdot \mathrm{cm}^{-2}\right)$ & $1.077,53-2.148,84$ & $1.656,22$ \\
Compressive strength parallel to grain, $\sigma_{\mathrm{tk}} / /\left(\mathrm{kg} \cdot \mathrm{cm}^{-2}\right)$ & $719,51-993,51$ & 861,55 \\
Shear strength, $\mathrm{T}\left(\mathrm{kg} \cdot \mathrm{cm}^{-2}\right)$ & $72,39-155,71$ & 119,61 \\
Tensile strength parallel to grain, $\sigma_{\mathrm{tr}} / /\left(\mathrm{kg} \cdot \mathrm{cm}^{-2}\right)$ & $2.015,67-2.904,45$ & $2.319,03$ \\
\hline${ }^{*}$ 20 test samples & &
\end{tabular}

Table 3: Physical and mechanical properties of several wood in strength level I-II (Martawijaya et al. 2005)

\begin{tabular}{lccccc}
\hline \multicolumn{1}{c}{ Wood } & $\begin{array}{c}\text { Specific } \\
\text { gravity } \\
\text { gr.cm }\end{array}$ & $\begin{array}{c}\text { MOE } \\
\mathrm{kg} \cdot \mathrm{cm}^{-2}\end{array}$ & $\begin{array}{c}\boldsymbol{\sigma}_{\mathrm{lt}} \\
\mathrm{kg} \cdot \mathrm{cm}^{-2}\end{array}$ & $\begin{array}{c}\mathbf{\sigma}_{\mathrm{tk}} / / \\
\mathrm{kg} \cdot \mathrm{cm}^{-2}\end{array}$ & $\begin{array}{c}\mathbf{T} \\
\mathrm{kg} \cdot \mathrm{cm}^{-2}\end{array}$ \\
\hline Shorea leavifolia & 0,91 & $187 \times 10^{3}$ & 1.243 & 680 & 102,8 \\
Shorea eleptica & 0,95 & $199 \times 10^{3}$ & 1.545 & 730 & 96,7 \\
Maranthes corymbesa & 0,96 & $170 \times 10^{3}$ & 1.286 & 620 & 67,4 \\
Aglaia subcuprea & 0,91 & $159 \times 10^{3}$ & 1.371 & 721 & 76,8 \\
Intsia bijuga & 0,84 & $158 \times 10^{3}$ & 1.478 & 777 & 104 \\
Dalbergia latifolia & 0,83 & $115 \times 10^{3}$ & 1.162 & 617 & 90,2 \\
Eusideroxylon zwa-geri & 1,04 & $184 \times 10^{3}$ & 1.431 & 734 & 117,4 \\
Trichadenia philippinensis & 0,86 & $157,7 \times 10^{3}$ & $1.023,7$ & 629,4 & 162 \\
Elateriospermum tapos & 0,81 & $168,7 \times 10^{3}$ & $1.116,4$ & 78,7 & 118,8 \\
Dillenia grandifolia & 0,80 & $178 \times 10^{3}$ & 1.045 & 131 & 97 \\
\hline Ebony (Diospyros celebica) ${ }^{*}$ & 0,821 & $180.425,87$ & $1.656,22$ & 861,55 & 119,61 \\
\hline
\end{tabular}

*Present study 


\subsection{Physical Properties}

Physical properties are quantitative characteristic of wood and its behavior against environmental influences (not including external applied forces) (Winandy 1994). Physical properties is very important because it affects on performance and strength of the wood used in structural applications. The often determined physical properties are moisture content and specific gravity. This value depends on the species and type of wood.

Test results of physical and mechanical properties test of Ebony wood are shown in Table 2 Based on the table it can be seen that moisture content of Ebony is in range of $9,18-16,82 \%$ with an average of $12,90 \%$. These results were in the range of air dried moisture content in Indonesia which ranged between $10-18 \%$. On standing trees (living trees) moisture content of wood could be in range of $25 \%-250 \%$ (Winandy 1994).

Moisture content is one of the most important variables that has to be considered when designing timber structures. Since it affects virtually all mechanical properties of timber, any inspection of wood buildings should include testing of the moisture content (Dolan 2004).

The physical properties test also found that specific gravity of Ebony is in range of $0,86-1,21{\mathrm{gr} . \mathrm{cm}^{-3}}$ with an average of 0.92 $\mathrm{gr} \mathrm{cm}^{-3}$. This value is greater than specific gravity at $12 \%$ moisture content of 10 -yearold of teak wood $\left(0,64 \mathrm{gr}^{\mathrm{cm}}{ }^{-3}\right)$ from Laos (Wanneng et al. 2014). Wood specific gravity is usually influenced by age of the trees. The older trees would have higher values of wood specific gravity. In addition, site and clone also influence wood specific gravity significantly (Kim et al. 2011).

Based on the specific gravity, Ebony wood can be classified into strength level class I (Table 1). This class of wood is also called as structural wood. Wood classified into this class can be used for heavy construction, not protected, and exposed to moist soil. Its use requires a structural analysis calculation.

\subsection{Mechanical Properties}

The mechanical properties is characteristics of material in response to an acting external force (external applied forces) (Winandy 1994). Engineers, architects and carpenters must consider this properties for design wooden structures. Mechanical properties consist of elastic properties (modulus of elasticity MOE, modulus of rigidity $\mathrm{G}$, and poison ratio $\mathrm{U}$ ) which shows a resistance to deformation and distortion, and strength properties which shows resistance in sustaining load.

MOE indicates the slope of stress-strain relationship curve in elastic conditions (elastic range) as in figure 3. Mechanical properties test shows that MOE of Ebony wood is ranging from 111.411,23 $215.771,95 \mathrm{~kg} \mathrm{~cm}^{-2}$ with an average of $180.425,87{\mathrm{~kg} . \mathrm{cm}^{-2}}^{2}$. This value is greater than Shorea leavifolia namely $187 \times 10^{3}$ $\mathrm{kg} . \mathrm{cm}^{-2}$, Shorea eleptica $199 \times 10^{3} \mathrm{~kg} . \mathrm{cm}^{-2}$, Cotilelobium spp. $190 \times 10^{3} \mathrm{~kg} \cdot \mathrm{cm}^{-2}$, and Eusideroxylon zwa-geri $184 \times 10^{3} \mathrm{~kg} . \mathrm{cm}^{-2}$. However, it is smaller than Dillenia grandifolia $178 \times 10^{3} \mathrm{~kg} . \mathrm{cm}^{-2}$, Shorea uliginosa $175 \times 10^{3} \mathrm{~kg} . \mathrm{cm}^{-2}$, Intsia bijuga $167 \times 10^{3} \mathrm{~kg} \cdot \mathrm{cm}^{-2}$, Maranthes corymbesa $170 \times 10^{3} \mathrm{~kg} \cdot \mathrm{cm}^{-2}$, and Garcinia nervosa $175,7 \times 10^{3} \mathrm{~kg} . \mathrm{cm}^{-2}$ (Martawijaya et.al., 2005). Based on MOE, Ebony wood is also classified into strength level class I (MOE > $125.000{\mathrm{~kg} . \mathrm{cm}^{-2}}^{-}$) (PKKI 1961).

Bending strength represents the maximum load capacity that is able to be borne by a bending element. Bending strength of wood is also affected by moisture content. Bending strength may increase as much as $4 \%$ for each $1 \%$ decrease in moisture content below the fiber saturation point (Dolan 2004). The results show that the bending strength values of Ebony wood ranged from 1077,53 to $2148,84 \mathrm{~kg} \cdot \mathrm{cm}^{-2}$ with an average of 1656,22 $\mathrm{kg} \cdot \mathrm{cm}^{-2}$. This value is still greater than another strong wood such as Shorea eleptica $1545 \mathrm{~kg}_{\mathrm{cm}}{ }^{-2}$, Eusideroxylon zwageri $1431 \mathrm{~kg} . \mathrm{cm}^{-2}$ (Martawijaya et al. 2005), and Shorea leavifolia $1243 \mathrm{~kg} . \mathrm{cm}^{-2}$ (Chauf 2005). 


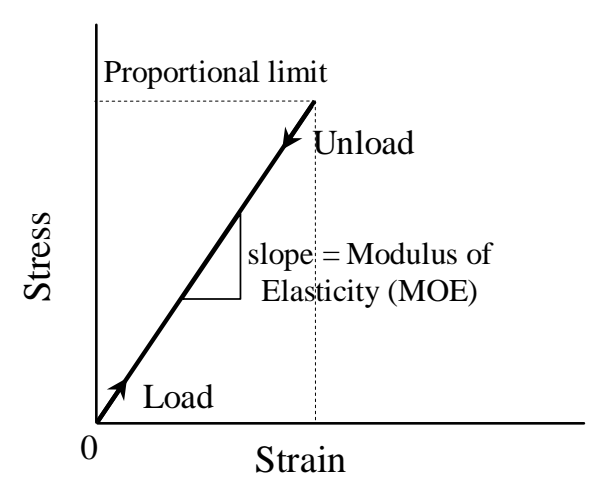

Figure 3: A typical stress-strain curve in elastic region

The compressive strength parallel to grain is a maximum value of stress that is still able to be borne by wood when receiving the compressive load in same direction to grain. Compressive testing to determine the stress should use specimen with ratio of its length dimension smaller than 11 (Wood Handbook 2010). Based on test results, the compressive strength parallel to grain of Ebony wood is ranged from 719,51 to $993,51 \mathrm{~kg} \cdot \mathrm{cm}^{-2}$ with an average of $861,55 \mathrm{~kg} . \mathrm{cm}^{-2}$. This value is greater than other woods like Eusideroxylon zwa-geri 734 kg.cm ${ }^{-2}$, Kokoona reflexa $782,1 \mathrm{~kg} \cdot \mathrm{cm}^{-2}$, Xanthophyllum flavescens $747,7 \mathrm{~kg} \cdot \mathrm{cm}^{-2}$, Intsia bijuga $777 \mathrm{~kg} \cdot \mathrm{cm}^{-2}$, and Shorea eleptica $730 \mathrm{~kg} \cdot \mathrm{cm}^{-2}$ (Martawijaya et.al., 2005). Compressive strength parallel to grain, at 15 percent moisture content, varies from 305,91 to $790,28 \mathrm{~kg} \cdot \mathrm{cm}^{-2}(30.0$ to $77.5 \mathrm{~N} \cdot \mathrm{mm}^{-2}$ ) (Duggal 2008).

The other mechanical properties belonging to strength properties are shear strength and tensile strength parallel to grain. Shear strength is the resistance to the acting shear loads. Based on the conducted research, the value of shear strength of Ebony is found ranged between 72,39 to $155,71 \mathrm{~kg} \cdot \mathrm{cm}^{-2}$ with an average of 119,61 $\mathrm{kg} . \mathrm{cm}^{-2}$. This value reaches 1,57 times the shear strength of wood Kumea Batu (Manilkara merrilliana) namely $76,01 \mathrm{~kg} . \mathrm{cm}^{-}$ 2 (Lempang et al. 2008).

Tensile strength parallel to grain is the maximum tensile stress that is capable detained by an element that receives a tensile load parallel to grain. Tensile strength parallel to the grain is two to four times the compressive strength and usually order 815.77 to $1937.46 \mathrm{~kg} . \mathrm{cm}^{-2}$ (80.0 to
190.0 N.mm ${ }^{-2}$ ) (Duggal 2008). Tensile strength parallel to grain of Ebony ranges from 2015,67 to $2904,45 \mathrm{~kg} \cdot \mathrm{cm}^{-2}$ with an average of $2319.03 \mathrm{~kg} \cdot \mathrm{cm}^{-2}$.

\section{Conclusion}

The average moisture content of Ebony is $12,90 \%$ and specific gravity is 0,92 $\mathrm{gr}_{\mathrm{cm}} \mathrm{cm}^{-3}$. The average value of MOE dan bending strength of Ebony are 180.425,87 $\mathrm{kg} \cdot \mathrm{cm}^{-2}$ and $1656,22 \mathrm{~kg} \cdot \mathrm{cm}^{-2}$ respectively. Meanwhile compressive strength parallel to grain, shear strength, and tensile strength parallel to grain are $861,55 \mathrm{~kg} . \mathrm{cm}^{-2}, 119,61$ $\mathrm{kg} . \mathrm{cm}^{-2}$, dan $2.319,03 \mathrm{~kg} . \mathrm{cm}^{-2}$ respectively.

The results conclude that Ebony wood could be classified into class I in strength level due to Indonesian Timber Construction Code, PKKI 1961 (MOE > 125,000 kg.cm ${ }^{-2}$ and specific gravity $>0.90$ ). Thus, this wood can be recommended for use in heavy constructions such as bridges (girder and floor) and the building structure (column, beam and floor).

\section{References}

Aghayere A \& Jason V. 2007. Structural Wood Design: A Practice-Oriented Approach Using the ASD Method. John Wiley \& Sons, Inc., New Jersey

Boen T. 2009. Constructing Seismic Resistant Masonry Houses in Indonesia. United Nation.

Chauf KA. 2005. Karakteristik Mekanik Kayu Kamper sebagai Bahan Konstruksi. Majalah IImiah MEKTEK. Vol $7: 41-47$.

Dolan JD. 2004. Timber Structures. Pp 628669 in Wai FC \& Eric ML (Eds) Handbook of Structural Engineering 2nd ed. USA.

Duggal SK. 2008. Building Materials - 3rd ed. New Age International (P) Ltd, New Delhi.

Kim NT, Matsumura J \& Oda K. 2011. Effect of growing site on the fundamental wood properties of natural hybrid clones of Acacia in Vietnam. Wood Science 57: 87-93. 
Lempang M \& Muhammad A. 2008. Anatomical Structure, Physical and Mechanical Properties of Kumea Batu Wood. Jurnal Penelitian Hasil Hutan. Vol.26(2): 138-147 (In Indonesian)

Martawijaya A., Kartasujana I, Mandang YI, Prawira SA, \& Kadir K. 2005. Atlas Kayu Indonesia, Jilid II. Departemen Kehutanan, Badan Penelitian dan Pengembangan Kehutanan, Bogor.

PKKI (Peraturan Konstruksi Kayu Indonesia). 1961. PKKI NI - 51961. Direktorat Jenderal Cipta Karya Departemen Pekerjaan Umum, Bandung.

Wanneng PX, Ozarska B, \& Daian MS. 2014. Physical Properties Of Tectona Grandis Grown In Laos. Journal of Tropical Forest Science 26(3): 389-396

Winandy JE. 1994. Wood Properties. Hal 549-561 dalam Arntzen, Charles J., (Editor) Encyclopedia of Agricultural Science. Vol. 4. October 1994. Academic Press, Orlando.

Wood Handbook. 2010. Wood as Engineering Material. Forest Product Laboratory. United States Department of Agriculture Forest Service, Madison.

Yancey CW. et al. 1998. A Summary of the Structural Performance of Single Family Wood Framed Housing, Building and Fire Research Laboratory, National Institute of Standards and Technology, Gaithersburg, MD. 